\title{
Comentário a \\ “CiênCIa e Ética EM Popper: A ÉTICA da \\ RESPONSABILIDADE DOS CIENTISTAS" - A VERDADE EM \\ Popper é IDEAL: É ÉTICO AFASTAR-SE DA FALSIDADE
}

Remi Schorn ${ }^{1}$

Referência do artigo comentado: DIAS, E. A. Ciência e ética em Popper: a ética da responsabilidade dos cientistas. Trans/Form/Açáo: revista de filosofia da Unesp, vol. 44, n. 3, p. 81-100, 2021.

Dias (2021) propóe uma argumentação consistente na defesa de uma hermenêutica bastante singular, no universo dos escritos sobre a filosofia de Karl Popper: a tese de que há, nos escritos popperianos, uma pressuposição de que o pesquisador deve ter responsabilidade científica e que isso decorre de uma postura ética incontornável para a busca da verdade. A afirmação popperiana de que "[...] a busca da verdade pressupóe a ética" (POPPER, 1993, p. 141) é tratada por Dias (2021, p. 05) como "[...] uma tese filosófica ou, mais precisamente, uma tese metacientífica”, por não poder ser nem verdadeira, nem falsa. Ou seja, uma vez que o processo de construção das ciências, como Popper o entendeu, não prevê a possibilidade objetiva do alcance da verdade, Dias compreende que a busca constante da verdade é uma diretriz ética do pensamento popperiano. A busca, entretanto, constitui a meta da ciência, um valor epistêmico primordial e um valor ético. Para sustentar sua

${ }^{1}$ Universidade Estadual do Oeste do Paraná (UNIOESTE), Toledo, PR - Brasil. (DD https://orcid. org/0000-0002-6739-7706 E-mail: remirs@hotmail.com

https://doi.org/10.1590/0101-3173.2021.v44n3.09.p111

\section{(i)}


leitura, a autora (2021, p. 06) se vale de Popper, quando afirma: "Creio que a verdade objetiva é um valor [...]; portanto um valor ético, talvez até um valor supremo; e a crueldade é o maior desvalor." (2006, p. 18). Do que Dias (2021, p. 06) corretamente infere que "[...] a verdade se identifica com o que é bom ou correto e orienta as discussóes na escolha de uma proposta."

Aqui, problematizo esse ponto da tese popperiana e apresento uma leitura divergente sobre o ponto exclusivo dos conceitos de verdade e de falsidade. A minha tese não ataca a argumentação da professora Elisabeth Dias e incide em uma instância do debate epistemológico: não considero que, em Popper, a verdade exerça função de guia e que haja linearidade na busca da verdade. Não concordo que a atividade dos cientistas possa ser assim explicada. A abordagem que proponho inverte, complexifica e corrige a tese mais usualmente conhecida de Popper sobre a relação da filosofia, da ciência, para com os conceitos de verdade e falsidade. Senão, vejamos:

Kant desafia-nos a usarmos a nossa inteligência em vez de confiarmos num guia, numa autoridade. Dever-se-ia tomar isso como um desafio para rejeitar até o perito científico enquanto guia, ou até a própria ciência. A ciência não tem autoridade. Não é o produto mágico dos dados, das observações. Não é um evangelho da verdade. Sou eu e vós que fazemos a ciência, do modo que sabemos fazê-la. Sois vós e eu que somos responsáveis por ela. (POPPER, 2000, p. 259).

Popper considera a ciência senso comum ampliado, esclarecido, reflexionado pelo pensamento crítico e imaginativo e, ao mesmo tempo, instrumento para a emancipação da ignorância, do medo, da superstição. A verdade, como ideia reguladora, não exerce a função de guia, mas de fiscal que aponta o erro e, ao fazê-lo, corrige e amplia o conhecimento. Para Popper (2000, p. 260), o conhecimento científico, a liberdade, a generosidade e o amor são “coisas pelas quais vale a pena morrer". A ciência é autoconstrução humana, permanentemente crítica e criativa, na qual humanidade e conhecimento se identificam.

Popper (2000, p. 7) defende que não há um telos ou algo como um método para chegar à verdade científica, nem mesmo para decidir se uma dada hipótese é ou não verdadeira ou provável. Diferentemente de teorias fundamentalistas, a ciência náo busca certeza e atua no delicado terreno da construção e reconstrução teórica de referências. A verossimilhança é o espólio, 
o pouco crédito a que faz jus a teoria que enfrentou tentativas falsificadoras e sobreviveu; entretanto, não é racional crer em teorias.

Registro, agora, a posição popperiana sobre o tema da aproximação à verdade para, então, criticá-la:

O que é, então, o objeto da nossa 'crença racional'? É, proponho, não a verdade, mas sim a verossimilhança [the truthlikeness] das teorias da ciência, tanto quanto elas tenham suportado uma crítica severa, incluindo testes. $\mathrm{O}$ que nós acreditamos (bem ou mal) não é que a teoria de Newton ou a de Einstein sejam verdadeiras, mas sim que são boas aproximaçóes à verdade, ainda que podendo ser superadas por outras melhores. (POPPER, 2000, p. 55, grifos do autor).

Popper usa "boas aproximaçóes à verdade" e isso não faz sentido, uma vez que não podemos nunca fixar a verdade e, mesmo que pudéssemos, náo temos métrica para tal. Por outro lado, podemos fixar a falsidade e, assim, demarcar quando abandonamos teorias e nos afastamos delas. Esse é nosso ponto: o que nos interessa é mostrar que a noção de afastamento da falsidade está em maior sintonia com a assimetria, corretamente registrada por Popper (2000, p. 185), entre verificação e falsificação, quando determina logicamente que "[...] um conjunto finito de enunciados básicos, se for verdadeiro, pode falsificar uma lei universal, ao passo que em condição alguma poderia verificar uma lei universal.” E, aqui, a evidência maior para nossa inferência:

Ainda que possamos, sensatamente, acreditar que o modelo copernicano (revisto por Newton) está mais perto da verdade do que o de Ptolomeu, não há meio de dizer a que ponto ele está perto da verdade: mesmo que pudéssemos definir uma métrica para a verossimilhança, [...] náo seríamos capazes de a aplicar, a náo ser que soubéssemos a verdade - coisa que náo sabemos. (POPPER, 2000, p. 61, grifos do autor).

O que Popper chamou de verossimilhança, como sinônimo de aproximação à verdade, seria, na atividade científica objetiva, alcançada por inferências indutivas fracas; todavia, ocorre que ele náo reconhece legitimidade na indução. Assim, para maior coerência ao sistema teórico popperiano, a noção de afastamento da falsidade se ancora na possibilidade lógica de detectar a falsidade e na impossibilidade lógica de detectar a verdade.

A atividade científica abandona as teorias falsificadas por um conjunto finito de asserçóes particulares aceitas em testes críticos. Em um tribunal 
jurídico, quando não há provas, o réu é inocente. No tribunal científico, sem provas da falsidade da hipótese em questão, ela se mantém. O princípio é o mesmo: não havendo provas, não há condenação; contudo, em havendo asserçôes de base aceitas que se constituam como contraexemplos à teoria geral, há falsificação completa. Logo, a eficácia científica se dá efetivamente na identificação do erro e na busca conjectural de sua correção. Esse movimento de afastamento em relação à falsidade identificada tem maior consonância com a concepção de verdade como veredito, defendida por Popper, em 1934 (2002, p. 58), e é substitutiva à complicada, e pouco objetiva, noção de verossimilhança presente nas obras tardias de Popper.

Nossa proposta supera o problema da ausência da métrica e permite demonstrar que, e quando, os cientistas abandonam asserçóes por serem falsas. Supera, igualmente, a dificuldade da noção de aproximação da verdade, que somente pode acontecer em asserçóes do passado. A noção de afastamento da falsidade atualiza epistemologicamente o efetivo trabalho dos cientistas. Ao encontrarem falsidades, eles refazem seu projeto investigativo, em uma busca criativa de novas teorias que expliquem melhor a realidade.

\section{REFERÊNCIAS}

DIAS, E. A. Ciência e ética em Popper: a ética da responsabilidade dos cientistas. Trans/ Form/Açáo: revista de filosofia da Unesp, v. 44, n. 3, p. 81-100, 2021.

POPPER, K. The Natural Selection and the Emergence of Mind. In: RADNITZKY, G.; BARTLEY, W.W. III (ed.). Evolutionary Epistemology, Racionality, and the Sociology of Knowledge. La Sale, Illinois: The Open Court, 1993. p. 139-155.

POPPER, K. Realism and the aim of science. London and New York: Routledge, 2000.

POPPER, K. The logic of scientific discovery. London and New York: Routledge Classic, 2002.

POPPER, K. Em busca de um mundo melhor. Sáo Paulo: Martins Fontes, 2006.

Recebido: 18/02/2021

Aceito: 23/02/2021 